\title{
Analisis Tingkat Mortalitas Sapi Bali pada Pemeliharaan Tradisional di Kecamatan Nanaet Dubesi Kabupaten Belu
}

Arkidius Meta ${ }^{\mathrm{a}}$

${ }^{a}$ Fakultas Pertanian, Universitas Timor, Kefamenanu, TTU - NTT, Indonesia.

\section{Article Info}

\section{Article history:}

Received 22 Mei 2018

Received in revised form 20 Juni 2018 Accepted 6 Juli 2018

\section{DOI:}

https://doi.org/10.32938/ja.v3i3.538

Keywords:

Sapi Bali, Karakteristik Peternak, Calving

rate, Mortalitas, Kepemilikan dan Pola

Pemeliharaan ternak

\section{Abstrak}

Penelitian bertujuan untuk mengetahui tingkat mortalitas Sapi Bali pada pemeliharaan tradisional di Kecamatan Nanaet Dubesi Kabupaten Belu. Penelitian dilakukan pada bulan Maret - April 2018. Metode yang digunakan adalah metode survei terhadap potensi ternak yang dipelihara oleh peternak. Variabel yang diamati meliputi karakteristik peternak, angka kelahiran, tingkat mortalitas, jumlah pemilikan dan pemotongan ternak, tingkat penjualan dan kehilangan ternak, dan tata laksana pemeliharaan ternak. Data dianalisis dengan menggunakan analisis deskriptif kuantitatif. Hasil penelitian menunjukkan bahwa karakteristik peternak sangat berpengaruh tatalaksana pemeliharaan ternak. Tingkat kelahiran pedet pada tahun 2016 sebanyak 378 ekor atau sebesar $45,11 \%$ dari 911 ekor induk, dan pada tahun 2017 sebanyak 460 ekor atau sebesar 54,89\% dari 934 ekor induk. Tingkat mortalitas Sapi Bali pada tahun 2016 sebesar 23,74\% atau sebanyak 61 ekor, dan pada tahun 2017 meningkat menjadi 76,26\% atau sebanyak 196 ekor. Sebagian besar (53,3\% atau 80 orang peternak) memelihara ternak dengan kisaran 5 sampai 10 ekor. Jumlah pemotongan ternak pada tahun 2016 sebanyak 1 ekor atau sebesar $0,06 \%$ dari jumlah populasi 1646 ekor, dan pada tahun 2017 sebanyak 39 ekor atau sebesar 2,24\% dari jumlah populasi 1740 ekor. Kehilangan ternak pada tahun 2016 sebanyak 14 ekor atau sebesar 0,9\% dari populasi 1640 ekor, dan pada tahun 2017 sebanyak 20 ekor dari populasi 1740 ekor. Disimpulkan bahwa pola pemeliharaan Sapi Bali secara tradisional di Kecamatan Nanaet Dubesi berdampak pada penurunan angka kelahiran, dan cenderung meningkatkan angka mortalitas setiap tahunnya.

\section{Pendahuluan}

Sapi Bali merupakan salah satu jenis ternak asli Indonesia yang banyak dipelihara oleh petani di Kecamatan Nanaet Dubesi. Hal tersebut disebabkan bangsa sapi ini memiliki beberapa keunggulan yang antara lain, tidak selektif dan mampu memanfaatkan pakan yang berkualitas rendah, memiliki tingkat adaptasi terhadap lingkungan yang cukup tinggi bahkan dapat hidup dan berproduksi baik di lahan kritis sedangkan bangsa sapi lainnya tidak demikian (Saputra, 2008). Selain itu, Sapi Bali mempunyai persentase karkas tinggi, daging yang sedikit lemak serta keempukan dagingnya tidak kalah dengan daging sapi impor. Di Nanaet Dubesi Sapi Bali cukup berperan dalam meningkatkan tingkat kesejahteraan masyarakat sehingga dijadikan sebagai komoditi unggulan yang perlu dikembangkan.

Ternak Sapi Bali meskipun telah menjadi komoditi unggulan di Kecamatan Nanaet Dubesi, perkembangan dan produktivitas ternak belum maksimal terutama disebabkan oleh kondisi pakan, pada musim hujan produktivitas ternak, terutama pertumbuhan dan perkembangan cukup meningkat yang dipengaruhi oleh kelimpahan pakan. Sebaliknya pada musim kemarau produktivitas ternak menurun, bahkan dapat menyebabkan tingkat kematian yang tinggi karena kurangnya pakan yang diperoleh ternak.

Tingkat kematian ternak Sapi Bali yang dipelihara secara ekstensif di Provinsi Nusa Tenggara Timur (NTT) sangat tinggi. Rata-rata kematian Sapi Bal di NTT saat ini adalah 35\%. Dipertegaskan tingginya tingkat kematian sapi oleh Mulik \& Jelantik (2009), dengan rentangan kematian ternak sangat luas yakni antara $6,12 \%$ hingga $65,5 \%$, tingkat kematian yang sedemikian merupakan yang tertinggi di Indonesia, yang dipengaruhi oleh dua puncak kematian antara lain, puncak kematian pertama adalah pada bulan pertama setelah dilahirkan karena pedet kekurangan susu induk sehingga tidak mencukupi kebutuhan pokok hidup dan pembentukan kekebalan tubuh yang kurang baik. Puncak kematian kedua adalah di awal musim hujan, yang dipengaruhi oleh merebaknya berbagai penyakit dan parasit yang menyerang pedet. Sapi Bali selain disebabkan oleh faktor pakan, juga disebabkan oleh kemampuan peternak yang belum optimal seperti kurangnya kontrol kesehatan, tatalaksana perkandangan yang belum memadai. Rendahnya kemampuan peternak disebabkan oleh faktor tingkat pendidikan rendah dan pemeliharaan yang masih tradisional (Thalib $d k k ., 2003$ )

Sapi Bali memiliki keunggulan sebagaimana tersebut di atas tetapi perlu diadakan di perbaikan penampilannya atau tingkat produktivitasnya. Penurunan performansi Sapi Bali mungkin disebabkan karena faktor bibit yaitu terjadinya inbreeding (kawin sedarah) dan tidak adanya pejantan unggul di dalam kelompok ternak masyarakat yang digunakan sebagai pemacek sehingga terjadi perkawinan acak tanpa kontrol dalam kelompok (Baco, 2001). Secara teoritis faktor-faktor penentu tingkat produktivitas dan performans ternak adalah faktor genetik (ternak) dan lingkungan (pakan, manajemen pemeliharaan, kesehatan, iklim dan sebagainya), namun demikian, faktor-faktor di atas belum sepenuhnya diperhatikan peternak dalam memelihara ternak sehingga sangat berdampak pada penurunan populasi ternak sapi itu sendiri, hal ini dipertegaskan oleh Baco (2010), survei di lapangan menunjukkan bahwa tingkat kebuntingan ternak sapi di peternakan rakyat masih rendah 20-40\%, umur melahirkan pertama 3-4 tahun, interval kelahiran panjang 1,5-2 tahun, bahkan tingkat kematian pedet sangat tinggi (30-50\%). Jika dibanding dengan potensi Sapi Bali pada umumnya produktivitas tersebut masih sangat rendah.

\section{Metode}

Penelitian dilakukan pada bulan Maret - April 2018. Peternak yang berpartisipasi sebagai responden dalam penelitian ini terdiri dari 3 (tiga) desa yang memiliki ternak di Kecamatan Nanaet Dubesi sebayak 150 orang yang tersebar di tiga (3) desa yaitu: Desa Nanaet: 50 KK, Desa Dubesi: 50 KK, Desa Fohoeka:50 KK. Jumlah populasi terbanyak di desa Dubesi: 1.551 ekor, Desa Fohoeka: 1.298 ekor dan desa Nanaet: 1.126 ekor. Alat-alat yang digunakan dalam penelitian ini antara lain seperti kuesioner, alat tulis menulis dan kamera sebagai alat dokumentasi. Penelitian ini dilakukan dengan metode deskriptif kuantitatif untuk menggambarkan pola pemeliharaan dari Tingkat Mortalitas Sapi Bali pada pemeliharaan tradisional. Persyaratan responden adalah memiliki ternak Sapi Bali minimal 5 (lima) ekor serta berpengalaman beternak minimal 5 (lima) tahun (Responden dipilih sekurang-kurangnya 30\% dari peternak yang memiliki ternak dan berpengalaman beternak seperti kriteria di atas). Adapun variabel-variabel yang diukur adalah karakteristik peternak yang meliputi: umur, jenis kelamin, tingkat pendidikan, pekerjaan, tanggungan keluarga, dan pengalaman beternak, angka kelahiran (Calving Rate) dan mortalitas menurut petunjuk Dania $d k k$., (2013), Jumlah pemilikan ternak, jumlah pemotongan ternak, jumlah ternak yang dijual, jumlah kehilangan ternak serta tatalaksana pemeliharaan. Data-data diambil dari data primer dan data sekunder. Data hasil penelitian dianalisis secara deskriptif, ditabulasi kemudian dihitung jumlah, persentase, rata-rata, simpangan baku yang berpedoman pada petunjuk teknik statistik Mean (Sugiyono, 2007).

\section{Hasil dan Pembahasan}

\subsection{Gambaran Umum Kecamatan Nanaet Dubesi}

Kecamatan Nanaet Dubesi merupakan salah satu kecamatan yang berada di wilayah Kabupaten Belu Provinsi Nusa Tenggara Timur. Adapun batas-batas wilayah Kecamatan Nanaet Dubesi yaitu: Barat berbatasan dengan Kecamatan Tasifeto Barat, Timur berbatasan dengan Kecamatan Kobalima Timur dan Negara Republik Demokrasi Timor Leste (RDTL), Utara berbatasan dengan Kecamatan Tasifeto Barat dan Negara Republik Demokrasi Timor Leste (RDTL), Selatan berbatasan dengan Kecamatan Raimanuk. Luas wilayah (daratan) Kecamatan Nanaet Dubesi adalah $60,25 \mathrm{~km}^{2}$ atau 50,40\% dari luas wilayah Kabupaten Belu. Secara astronomis Kecamatan Nanaet Dubesi terletak antara $09^{0} 16^{0} 13^{0} 9^{0} \mathrm{LS}$ dan antara $124^{0} 57^{0} 44,8^{0}$ BT (BPS Kab. Belu, 2016).

Seperti halnya di wilayah lain di Indonesia, Kecamatan Nanaet Dubesi juga hanya dikenal dua musim yaitu musim kemarau dan musim hujan. Secara umum, musim kemarau terjadi pada Juni sampai September, sedangkan musim hujan terjadi pada bulan Desember sampai Maret (BPS Kab. Belu, 2016). Namun setahun terakhir telah terjadi perubahan periode musim yang cukup signifikan. Waktu hujan menjadi lebih panjang dibanding tahun-tahun sebelumnya. Data BPS Kab. Belu (2016) jumlah rumah tangga usaha peternakan khususnya ternak Sapi Bali di 4 (empat) desa pada Kecamatan Nanaet Dubesi tahun 2016 adalah sebanyak 4.738 ekor. Selain ternak Sapi Bali, terdapat juga berbagai jenis ternak yang dipelihara oleh masyarakat di Kecamatan Nanaet Dubesi antara lain seperti pada Tabel 1.

Tabel 1. Jumlah Populasi Ternak menurut Jenis Ternak di Kecamatan Nanaet Dubesi Kabupaten Belu, Tahun 2016.

\begin{tabular}{lc}
\hline Jenis ternak & Jumlah ternak \\
\hline Sapi Perah & - \\
Sapi Bali & 4.738 \\
Kerbau & 86 \\
Kuda & 84 \\
Babi & 1.745 \\
Kambing & 524 \\
Ayam Buras & 4.875 \\
Ayam Ras Petelur & - \\
Bebek & - \\
Itik & 18 \\
\hline
\end{tabular}

3.2. Karakteristik Peternak di Kecamatan Nanaet Dubesi Kabupaten Belu

Karakteristik peternak meliputi tingkat pendidikan, umur, pekerjaan utama dan pengalaman usaha. Komponen karakteristik ini diduga mempunyai 
hubungan yang erat dengan tingkat keberhasilan peternak dalam mengelola usaha ternaknya.

\section{a. Tingkat Pendidikan Peternak}

Tingkat pendidikan menunjukkan pengetahuan dan daya pikir yang dimiliki oleh seorang responden dan berpengaruh terhadap kematangan dirinya dalam bersikap, pengambilan keputusan dan berperilaku (Utami, 2015). Oleh karena itu maka tingkat pendidikan dapat diklasifikasikan menjadi empat bagian yaitu: Tidak sekolah SR/SD, SMP, SMA dan Sarjana. Adapun deskripsi profil responden menurut jenis pendidikan seperti terlihat pada Tabel 2. di bawah ini.

Data pada Tabel 2. menunjukkan bahwa rata-rata peternak yang tidak sekolah sebanyak 38 orang dari 150 responden dengan nilai persentase $25,33 \%$; pendidikan SR/SD sebanyak 93 orang dari 150 responden dengan nilai persentase $62 \%$; pendidikan SMP sebanyak 5 orang dari 150 responden atau $3,3 \%$; pendidikan SMA sebanyak 12 orang dari 150 responden dengan nilai persentase $8 \%$ dan pendidikan sarjana sebanyak 2 orang dari 150 responden atau $1,3 \%$. Hal ini menggambarkan bahwa peternak yang berpendidikan SR/SD sebanyak 93 orang dari 150 responden atau $62 \%$, hal ini diduga bahwa umumnya responden lebih memilih jadi peternak ketimbang bersekolah dengan alasan yang beragam sehingga peternak yang berada di Kecamatan Nanaet Dubesi hanya mengenyam pendidikan terakhir Sekolah Dasar (SD) atau sederajatnya atau bahkan tidak bersekolah. Menurut Waris $d k k$., (2015), pendidikan tidak mempengaruhi keberlangsungan usaha ternak, melainkan pengalaman beternak dan jumlah kepemilikan. Hasil penelitian ini bertolak belakang dengan penelitian Makatita (2013) pendidikan merupakan salah satu faktor yang menunjang keberhasilan usaha skala kecil, dengan asumsi semakin tinggi tingkat pendidikan, semakin baik pengetahuannya dalam mengelola usaha.

Tabel 2. Tingkat Pendidikan Peternak di Kecamatan Nanaet Dubesi Kabupaten Belu

\begin{tabular}{clcc}
\hline NO & Tingkat Pendidikan & Jumlah & Persentase \\
\hline 1 & Tidak sekolah & 38 & 25,33 \\
2 & SR/SD & 93 & 62 \\
3 & SMP & 5 & 3,3 \\
4 & SMA & 12 & 8 \\
5 & Sarjana & 2 & 1,3 \\
\hline Total & & 150 & 100 \\
\hline
\end{tabular}

\section{b. Umur Peternak}

Umur merupakan salah satu yang mempengaruhi perilaku dan kinerja dalam suatu usaha yang dilakukan di mana produktivitas kerja akan meningkat bila masih dalam kondisi umur yang produktif dan semakin menurun seiring bertambahnya umur seseorang. Pengelompokan usia dapat dibagi menjadi 3 (tiga) kelompok besar yaitu 1 . Usia tidak produktif antara $<21$ tahun. 2. Usia produktif 22-55 tahun, 3. Usia $>56$ tahun tidak produktif (Manula).

Tabel 3. Umur Peternak di Kecamatan Nanaet Dubesi Kabupaten Belu

\begin{tabular}{|c|c|c|c|c|}
\hline No. & & nis Umur & Jumlah & Persentase \\
\hline 1 & $<24$ & Tidak Produktif & 0 & 0 \\
\hline 2 & $25-54$ & Produktif & 82 & 54,6 \\
\hline 3 & $55-80$ & Tidak produktif & 68 & 45,4 \\
\hline
\end{tabular}

Tabel 3. menunjukkan bahwa dari hasil analisis yang diperoleh umumnya peternak di Kecamatan Nanaet Dubesi berada pada kelompok usia produktif sebanyak 82 orang dari 150 orang responden atau 54,6\%. Sementara usia manula atau tidak produktif sebanyak 68 orang atau $45,4 \%$. Hal ini diduga bahwa peternak di Kecamatan Nanaet Dubesi masih memiliki semangat usaha beternak yang tinggi, tergambar bahwa semakin tinggi usia seseorang semakin kecil ketergantungan terhadap orang lain atau berperilaku mandiri. Menurut Murwanto, (2008), peternak yang berumur produktif biasanya memiliki pola pikir yang dinamis dan kemampuan fisik yang prima dalam mengelola usaha ternaknya. Ditambahkan oleh Chamdi (2003) mengemukakan, semakin muda usia peternak (usia produktif 20-45 tahun) umumnya rasa keingintahuan terhadap sesuatu semakin tinggi dan minat untuk mengadopsi terhadap introduksi teknologi semakin tinggi. Soekartawi (2002), menyatakan bahwa para petani yang berusia lanjut biasanya fanatik terhadap tradisi dan sulit untuk diberikan pengertian-pengertian yang dapat mengubah cara berpikir dan cara pandang guna meningkatkan kemajuan dari segi usaha taninya, cara kerja dan cara hidupnya. Petani ini bersikap apatis terhadap adanya teknologi baru.

c. Pekerjaan Peternak

Deskripsi karakteristik responden menurut jenis pekerjaan yaitu menguraikan atau memberikan gambaran mengenai identitas responden menurut jenis pekerjaan. Dalam deskripsi karakteristik responden dikelompokkan menurut jenis pekerjaan responden yang dapat dilihat pada Tabel 4.

\begin{tabular}{lccc}
\multicolumn{4}{c}{ Tabel 4. Pekerjaan Peternak di Kecamatan Nanaet Dubesi Kabupaten Belu } \\
\hline No. & Pekerjaan & Jumlah & Persentase \\
\hline 1. & Petani & 148 & 98,7 \\
2. & PNS & 2 & 1,3 \\
\hline & $\Sigma$ & 150 & 100 \\
\hline
\end{tabular}

Berdasarkan Tabel 4. hasil analisis yang menunjukkan pekerjaan petani sebanyak 148 orang dari 150 responden atau 98,7\%; pekerjaan PNS sebanyak 2 orang dari 150 responden atau $1,3 \%$. Hal ini dikarenakan sebagian besar penduduk di seluruh Kecamatan Nanaet Dubesi bermata pencaharian sebagai petani dengan jumlah 148 orang atau 98,7\%. Umumnya peternak yang berada di Kecamatan Nanaet Dubesi petani namun terdapat pula yang berprofesi sebagai PNS sebanyak 2 orang hal ini dikarenakan tanggung jawab pemeliharaan dan penggembalaan dilakukan oleh istri atau anggota keluarga lain.

d. Jumlah Tanggungan Keluarga

Jumlah tanggungan keluarga merupakan jumlah anggota keluarga yang menjadi tanggungan responden untuk dinafkahi dan sebagai salah satu faktor yang dapat mempengaruhi peningkatan populasi ternak Sapi Bali yang berkorelasi dengan penggunaan tenaga kerja keluarga yang bertanggung jawab terhadap perkembangan ternak Sapi Bali.

Tabel 5. Jumlah Tanggungan Keluarga Peternak di Kecamatan Nanaet Dubesi Kabupaten Belu

\begin{tabular}{cccc}
\hline Jumlah Tanggungan Keluarga & Kategori & \multicolumn{2}{c}{ Frekuensi Persentase (\%) } \\
\hline 1. $2-5$ orang & Kurang & 102 & 68,0 \\
2. $6-9$ orang & Cukup & 46 & 30,7 \\
3. $>9$ orang & Besar & 2 & 1,3 \\
\hline Total & & 150 & 100
\end{tabular}

Data Tabel 5. menunjukkan bahwa rata-rata peternak yang berada di Kecamatan Nanaet Dubesi umumnya memiliki tanggungan keluarga. Hal ini terlihat pada data hasil penelitian sebagai berikut, Memiliki tanggungan antara 2-5 orang sebanyak 102 orang atau dengan persentase sebesar $68,0 \%$, jumlah tanggungan 6-9 orang sebanyak 46 orang atau 30,7\%, sementara jumlah tanggungan keluarga lebih dari 9 orang sebanyak 2 orang atau sebesar 1,3\% dari total responden yang diambil sebanyak 150 orang peternak. Data ini juga menggambarkan bahwa umumnya peternak/responden yang memiliki jumlah tanggungan keluarga, maka waktu yang disediakan responden untuk bekerja semakin efektif, dengan sendirinya partisipasi anggota keluarga terhadap penggunaan tenaga kerja pada usaha pemeliharaan semakin efektif dalam menyumbangkan kontribusi terhadap peningkatan populasi. Menurut Hartono (2005), tenaga kerja pada usaha peternakan pada umumnya masih menggunakan tenaga kerja keluarga dalam usaha pengembangan skala usaha beternak sapi.

e. Pengalaman Usaha Peternak

Deskripsi responden menurut pengalaman usaha menguraikan mengenai seberapa lama responden menggeluti usaha/memelihara ternak Sapi Bali yang menjadi sampel dalam penelitian ini. Pengalaman usaha yang telah terpatri dalam diri seseorang akan turut mempengaruhi sikap dan perilakunya dalam bertindak Oleh karena itulah perlu dideskripsi karakteristik responden menurut pengalaman usaha.

Tabel 6. Pengalaman Beternak dan Rataan Jumlah Kepemilikan Ternak oleh Peternak di Kecamatan Nanaet Dubesi Kabupaten Belu

\begin{tabular}{cccc}
\hline No. & Pengalaman Beternak & Jumlah & Persentase \\
\hline 1 & $5-10$ & 24 & 16 \\
2 & $11-20$ & 43 & 28,7 \\
3 & $>21$ & 83 & 55,3 \\
\hline Total & $\Sigma$ & 150 & 100 \\
\hline
\end{tabular}

Data Tabel 6. menunjukkan bahwa dari data pengalaman beternak 5-10 tahun yaitu sebanyak 24 orang dari 150 responden atau 16\%; pengalaman beternak 11-20 tahun sebanyak 43 orang dari 150 responden atau $28,7 \%$; dan pengelaman beternak $>21$ sebanyak 83 orang dar 150 responden atau 55,3\% hasil menunjukkan bahwa rata-rata peternak di Kecamatan Nanaet Dubesi umumnya berpengalaman di atas 21 tahun, hasil ini menunjukkan bahwa pengalaman responden dalam memelihara ternak yang sangat berkaitan dengan minat, keterampilan dan kompetensi peternak hal ini akan berdampak terhadap tingkat keberhasilan beternak Sapi Bali di Kecamatan Nanaet Dubesi akan berpotensi jumlah ternaknya yang memiliki keterampilan dan pengalaman dibidang peternak hal ini akan berdampak terhadap peningkatan populasi ternak. Hal ini sejalan dengan penelitian terdahulu yang dilakukan oleh Utami, (2016), pengalaman beternak berkorelasi nyata dengan skala usaha ternak. Ditambahkan oleh Idris $d k k$., (2009) bahwa minat di pengaruhi oleh pengalaman beternak karena semakin lama pengalaman beternak dalam beternak maka semakin tinggi minat untuk mengembangkan usahanya.

\subsection{Faktor-Faktor yang Mempengaruhi Tingkat Mortalitas Ternak Sapi Bali Di Kecamatan Nanaet Dubesi}

a. Mortalitas Ternak Sapi Bali

Banyaknya ternak yang mati dihitung dalam persentase pada suatu periode tertentu, tingkat mortalitas ternak di Kecamatan Nanaet Dubesi dapat dibagi menjadi tiga kelompok besar antara lain : 1. Kematian Pedet, 2. Kematian Muda, 3. Kematian Dewasa. Kematian pedet adalah jumlah angka kematian pedet per tahun dibagi dengan jumlah kelahiran pedet yang dinyatakan dalam persen. Kematian muda adalah jumlah angka kematian muda dibagi dengan total populasi muda per tahun yang dinyatakan dalam persen. Kematian dewasa adalah jumlah angka kematian dewasa dibagi dengan jumlah populasi dewasa per tahun yang dinyatakan dalam persen. Dinamika tingkat mortalitas ternak Sapi Bali di kecamatan Nanaet Dubesi sebagai berikut : 
Tabel 7. Angka Mortalitas Ternak Sapi Bali di Kecamatan Nanaet Dubesi Kabupaten Belu

\begin{tabular}{cccccccccc}
\hline Jenis & \multicolumn{3}{c}{ Tahun } & \multicolumn{3}{c}{ Populasi } & \multicolumn{3}{c}{ Persentase mortalitas } \\
\cline { 2 - 10 } Ternak & 2016 & 2017 & $\Sigma$ & 2016 & 2017 & $\Sigma$ & 2016 & 2017 & $\Sigma$ \\
\hline Pedet & 52 & 131 & 183 & 378 & 460 & 838 & 13,76 & 28,48 & 42,24 \\
Muda & 4 & 24 & 28 & 380 & 451 & 831 & 1,05 & 5,32 & 6,37 \\
Dewasa & 5 & 41 & 46 & 1266 & 1289 & 2555 & 0,39 & 3,18 & 3,57 \\
\hline$\Sigma$ & 61 & 196 & 257 & 2557 & 2674 & 5231 & 15,2 & 36,98 & 52,18 \\
\hline
\end{tabular}

Data hasil penelitian pada Tabel 7. menunjukkan bahwa angka Mortalitas pedet pada dua (2) tahun terakhir sebanyak 183 ekor atau 42,24\%, ternak muda sebanyak 28 ekor atau 6,37\% dan ternak dewasa sebanyak 46 ekor atau 3,57\%. Rata-rata tingkat kematian ternak pada tahun 2016 dan 2017 sebesar 52,18\% dari total populasi sebanyak 5.231 ekor. Tingginya kematian pedet ternak Sapi Bali yang ada di Kecamatan Nanaet Dubesi, diduga dipengaruhi oleh beberapa faktor antara lain:

- Karakteristik peternak yang meliputi, tingkat pendidikan, umur peternak, pengalaman, jumlah tanggungan, dan pekerjaan peternak yang tidak mendukung tata laksana pemeliharaan secara baik.

Kualitas dan kuantitas pakan, yang dihasilkan tidak memadai ini terlihat pada lokasi penelitian umumnya jumlah pakan pada musim paceklik terbatas dan ternak hanya mengonsumsi rumput alam yang berdampak pada kurangnya kolostrum yang dihasilkan oleh induk berpengaruh terhadap menurunnya daya kekebalan tubuh pedet. Jumlah angka mortalitas pedet akibat kurangnya kualitas dan kuantitas pakan sebanyak 58 ekor.

Iklim seperti curah hujan yang berkepanjangan yang mengakibatkan tingkat kelembapan kandang yang tinggi. Jumlah mortalitas sebanyak 82 ekor selama tahun 2016 dan 2017 akibat perubahan iklim.

- Ternak terindikasi oleh adanya infeksi penyakit tertentu seperti bloat, telasiasis, Septichaemia Epizootic (SE) dan diare, dengan jumlah mortalitas pedet selama 2016 dan 2017 sebanyak 42 ekor.

$\circ \quad$ Serangan predator lain pada pedet yang baru lahir. Serangan predator lain di tempat penelitian sebanyak 1 ekor yang diduga dimakan oleh ternak babi.

- Program vaksinasi: juga tidak diberikan vaksinasi karena pada saat melakukan vaksin pedet tersebut belum lahir.

Hubungan antara tingkat mortalitas dan lama beternak, tingkat pendidikan serta umur peternak, data hasil penelitian menunjukkan bahwa antara pengalaman, tingkat pendidikan serta umur peternak, memberikan korelasi yang nyata terhadap rendahnya angka kematian. Hal ini disebabkan bahwa semakin lama seseorang beternak dengan tingginya mengenyam tingkat pendidikan maka pola pemahaman dan upaya preventif terhadap angka mortalitas semakin tinggi dan berkontribusi terhadap peningkatan populasi ternak.

Menurut hasil penelitian Asana $d k k$., (2016), penyebab kematian ternak Sapi Bali di daerah penelitian disebabkan karena sistem pemeliharaannya ternak masih bersifat tradisional dan kurang terampilnya peternak dalam menangani ternak yang sakit. Ditambahkan oleh Mulik \& Jelantik (2009), dengan rentangan kematian ternak sangat luas yakni antara $6,12 \%$ hingga $65,5 \%$. Tingkat kematian yang sedemikian merupakan yang tertinggi di Indonesia, yang dipengaruhi oleh dua puncak kematian antara lain, puncak kematian pertama adalah pada bulan pertama setelah dilahirkan karena pedet kekurangan susu induk sehingga tidak mencukupi kebutuhan pokok hidup dan pembentukan kekebalan tubuh yang kurang baik. Puncak kematian kedua adalah di awal musim hujan, yang dipengaruhi oleh merebaknya berbagai penyakit dan parasit yang menyerang pedet. Hal tersebut menyebabkan ternak mudah terserang penyakit, mengalami kecelakaan, keracunan dan di serang binatang pemangsa.

b. Angka Kelahiran (Calving Rate)

Jumlah anak yang lahir per tahun dibagi dengan jumlah populasi pada struktur populasi dikali 100\% (Dania dkk., 2013).

Data hasil pada Tabel 8. menunjukkan bahwa tingkat kelahiran pedet di kecamatan Nanaet Dubesi pada tahun 2017 sebanyak 460 ekor atau 55,1\% sementara di tahun 2016 sebanyak 375 ekor atau sebesar 44,9\% dari total kelahiran 2016/2017 sebanyak 835 ekor. Penunjang angka kelahiran ternak Sapi Bali dapat dipengaruhi oleh kualitas dan kuantitas pakan, air minum, ketersediaan suplai air susu induk, dan rasio pejantan yang merata serta iklim.

Tabel 8. Angka Kelahiran Ternak Sapi Bali di Kecamatan Nanaet Dubesi Kabupaten Belu

\begin{tabular}{|c|c|c|c|c|c|c|c|}
\hline \multirow{2}{*}{ No. Tahun } & \multirow{2}{*}{$\begin{array}{l}\text { Populasi } \\
\text { Induk }\end{array}$} & \multicolumn{3}{|c|}{ Kelahiran Pedet Ternak } & \multicolumn{3}{|c|}{ Persentase (\%) Pedet } \\
\hline & & Jantan & Betina & $\Sigma$ & Jantan & Betina & $\Sigma$ \\
\hline 2016 & 911 & 182 & 193 & 375 & 21,8 & 23,1 & 44,9 \\
\hline 22017 & 934 & 214 & 246 & 460 & 25,6 & 29,5 & 55,1 \\
\hline Total & 1845 & 396 & 439 & 835 & 47,4 & 52,6 & 100,0 \\
\hline
\end{tabular}

Penurunan populasi pedet pada tahun 2016 diduga dipengaruhi oleh beberapa hal, rendahnya pendidikan peternak dan pengalaman dalam usaha beternak Sapi Bali, pola pemeliharaan yang masih tradisional, ketersediaan pakan pada musim paceklik dan rendahnya pengolahan limbah pertanian menjadi pakan alternatif. Menurut Asana, (2016), tingginya angka kelahiran Sapi Bali pada daerah penelitian disebabkan karena ketersediaan pakan yang memadai pada lahan ataupun padang penggembalaan. Hal ini akibat kondisi iklim terutama curah hujan yang dapat berpengaruh pada ketersediaan pakan ternak di musim hujan.

\section{c. Jumlah Kepemilikan Ternak}

Jumlah kepemilikan ternak merupakan jumlah ternak yang dimiliki oleh peternak yang ada di Kecamatan Nanaet Dubesi yang meliputi, banyaknya pedet, muda, dan dewasa yang dimiliki peternak saat ini. Hasil penelitian Tabel 9. menunjukkan bahwa peternak di Kecamatan Nanaet Dubesi umumnya memiliki ternak sebanyak 5-10 ekor dengan persentase sebanyak 53,3\%. Klasifikasi ini menggambarkan bahwa peternak di Kecamatan Nanaet Dubesi, rata-rata memiliki ternak 5-10 ekor, hal ini tidak sebanding dengan luas lahan penggembalaan yang cukup luas sebesar $60,25 \mathrm{KM}^{2}$, hal ini diduga bahwa kepemilikan ternak saat ini yang dimiliki oleh peternak merupakan harta warisan yang ditinggalkan oleh orang tua mereka sebelum meninggal dunia, oleh Karena itu mereka mempertahankan ternak sapi demi meningkatkan pendapatan keluarga. Jumlah kepemilikan yang rendah dipengaruhi oleh rendahnya motivasi terhadap kepemilikan ternak melainkan hanya berorientasi pada bidang peternakan lain seperti usaha pengembangan ternak babi, kambing dan pertanian. Hal ini sejalan dengan pendapat Siregar (2013), Keberhasilan usaha ternak sapi potong bergantung pada tiga unsur yaitu bibit, pakan, dan manajemen.

Tabel 9. Jumlah Kepemilikan Ternak di Kecamatan Nanaet Dubesi Kabupaten Belu

\begin{tabular}{cccc}
\hline Jumlah ternak & Kategori & Frekuensi & Persentase \\
\hline 5-10ekor & Kurang & 80 & 53,3 \\
$11-20$ ekor & Sedang & 43 & 28,7 \\
21-30 ekor & Banyak & 17 & 11,3 \\
$>30$ ekor & sangat banyak & 10 & 6,3 \\
\hline
\end{tabular}

\section{d. Jumlah Pemotongan Ternak}

Pemotongan ternak dapat dilakukan di Kecamatan Nanaet Dubesi, apabila ada kegiatan sosial budaya seperti pembuatan rumah adat, resepsi pernikahan, dan kedukaan sebagai simbol kearifan lokal masyarakat Kecamatan Nanaet Dubesi. Data Tabel 10. menunjukkan bahwa rata-rata pemotongan terjadi pada betina dewasa sebanyak 38 ekor dengan persentase 4,07\%, sedikitnya angka pemotongan dikarenakan kegiatan pemotongan ternak hanya dilakukan pada kegiatan-kegiatan tertentu. Hasil penelitian umumnya pemotongan ternak hanya dilakukan untuk upacara adat dan pernikahan serta kedukaan sebagai simbol kearifan lokal. Menurut Sariubang $d k k$., (2010), simbolisme dipakai sebagai alat tukar maupun sebagai mas kawin misalnya untuk menggadaikan sawah digunakan standar kerbau, atau pun melamar gadis digunakan kerbau sebagai ukuran yang sekaligus menunjukkan strata sosial gadis yang dilamar, tergantung jumlah kerbau yang ditentukan sebagai mas kawin yang akan dibayar bila terjadi perceraian.

Tabel 10. Jumlah Pemotongan Ternak Sapi Bali di Kecamatan Nanaet Dubesi Kabupaten Belu

\begin{tabular}{ccccccccc}
\hline \multicolumn{2}{c}{ Pemotongan } & \multicolumn{2}{c}{ Jumlah } & \multicolumn{2}{c}{ Populasi } & \multicolumn{3}{c}{ Persentase (\%) } \\
\cline { 2 - 9 } Jenis ternak & 2016 & 2017 & 2016 & 2017 & 2016 & 2017 & $\%$ \\
\hline \multirow{2}{*}{ Muda } & Jantan & 0 & 0 & 182 & 220 & 0 & 0 & 0 \\
& Betina & 0 & 1 & 198 & 231 & 0 & 0.43 & 0.43 \\
\hline \multirow{2}{*}{ Dewasa } & Jantan & 0 & 1 & 355 & 355 & 0 & 0.28 & 0.28 \\
& Betina & 1 & 37 & 911 & 934 & 0.11 & 3.96 & 4.07 \\
\hline \multicolumn{2}{c}{} & 1 & 39 & 1646 & 1740 & 0.06 & 2.24 & 2.30 \\
\hline
\end{tabular}

\section{e. Angka Kehilangan}

Angka kehilangan adalah penurunan populasi ternak yang dapat disebabkan oleh pencurian ternak yang disebabkan oleh kelalaian peternak sendiri. Data Hasil penelitian pada Tabel 11. menunjukkan bahwa total kehilangan ternak di Kecamatan Nanaet Dubesi sebanyak 34 ekor atau dengan persentase sebanyak 2,0\%. Secara geografis letak Kecamatan Nanaet Dubesi yang berbatasan dengan Negara Republik Demokrat Timor Leste yang secara umun rawan akan kehilangan ternak namun data ini menunjukkan bahwa kehilangan ternak dapat diminimalisir oleh peternak, seperti menggembalakan ternak di padang penggembalaan dan dikandangkan pada malam hari. Untuk meminimalisir tingkat kehilangan ternak perlu diadakannya asuransi ternak di wilayah perbatasan, menurut Pontianakpos.com.id (2016), asuransi ini memberikan jaminan perlindungan dari risiko kematian dan kehilangan sapi sehingga dapat mengatasi kerugian usaha dari pemerintah.

Tabel 11. Angka kehilangan ternak Sapi Bali di Kecamatan Nanaet Dubes Kabupaten Belu

\begin{tabular}{ccccccccc}
\hline \multirow{2}{*}{$\begin{array}{c}\text { Kehilangan } \\
\text { Jenis Ternak }\end{array}$} & \multicolumn{2}{c}{ Frekuensi } & \multicolumn{2}{c}{ Populasi } & \multicolumn{3}{c}{ Persentase } \\
\cline { 2 - 9 } Muda & 2016 & 2017 & 2016 & 2017 & 2016 & 2017 & Total \\
\hline \multirow{2}{*}{ Jantan } & 3 & 2 & 182 & 220 & 1.6 & 0.9 & 2.6 \\
& Betina & 2 & 2 & 198 & 231 & 1.0 & 0.9 & 1.9 \\
\hline \multirow{2}{*}{ Dewasa } & Jantan & 2 & 3 & 355 & 355 & 0.6 & 0.8 & 1.4 \\
& Betina & 7 & 13 & 911 & 934 & 0.8 & 1.4 & 2.2 \\
\hline \multicolumn{2}{c}{ Total } & 14 & 20 & 1646 & 1740 & 0.9 & 1.1 & 2.0
\end{tabular}

f. Tingkat Penjualan Ternak

Tingkat kebutuhan masyarakat di Kecamatan Nanaet Dubesi yang beragam dan bervariatif memaksa peternak untuk menjual ternak yang dimilikinya demi terpenuhi akan kebutuhan tersebut antara lain: biaya 
pendidikan anak, pemenuhan kebutuhan dalam rumah tangga, pembangunan rumah, kegiatan sosial budaya.

Tabel 12. Angka penjualan ternak Sapi Bali di Kecamatan Nanaet Dubesi Kabupaten Belu

\begin{tabular}{cccccccc}
\hline \multirow{2}{*}{$\begin{array}{c}\text { Penjualan jenis } \\
\text { ternak }\end{array}$} & \multicolumn{2}{c}{ Jumlah } & \multicolumn{2}{c}{ Populasi } & \multicolumn{2}{c}{ Persentase } \\
\cline { 2 - 7 } Muda & 2016 & 2017 & 2016 & 2017 & 2016 & 2017 \\
\hline \multirow{2}{*}{ Jantan } & 4 & 22 & 182 & 220 & 2,2 & 12,09 \\
& Betina & 2 & 1 & 198 & 231 & 1,01 & 0,51 \\
\hline \multirow{2}{*}{ Dewasa } & Jantan & 10 & 115 & 355 & 355 & 2,82 & 32,39 \\
& Betina & 6 & 30 & 911 & 934 & 0,66 & 3,29 \\
\hline \multicolumn{2}{c}{ Total } & 22 & 168 & 1646 & 1740 & 6,68 & 48,28 \\
\hline
\end{tabular}

Data hasil Tabel 12. menunjukkan bahwa rata-rata tingkat penjualan ternak Sapi Bali di Kecamatan Nanaet Dubesi tertinggi pada tahun 2017 sebanyak 168 ekor atau 48,28\% dari populasi 1740 ekor. Umumnya penjualan pada jenis ternak jantan, melihat bobot badan dan performens yang tinggi yang berkorelasi dengan perilaku pasar yang dapat menentukan kualitas ternak yang dijual. Hal ini dipengaruhi oleh tingkat kebutuhan peternak yang berkorelasi dengan besarnya nilai jual ternak. Ternak jantan memiliki nilai harga yang lebih tinggi sebaliknya nilai jual ternak betina lebih rendah.

Tingkat penjualan ternak yang dilakukan selain untuk membiayai kebutuhan hidup terdapat pula penjualan ternak dilakukan untuk membangun rumah, biaya pendidikan anak serta memenuhi kegiatan sosial budaya. Menurut Trigestianto $d k k,$. (2013), perilaku pasar merupakan proses/gerak yang terjadi di pasar, yang berkaitan dengan faktor perilaku pasar, antara lain penentuan kualitas ternak yang dijual pada konsumen.

\section{Simpulan}

Dapat disimpulkan bahwa mortalitas Sapi Bali di Kecamatan Nanaet Dubesi di Kabupaten Belu pada tahun 2016 mencapai 61 ekor $(15,1 \%)$ sedangkan pada tahun 2017 mencapai 196 ekor (36,98\%). Calving rate pedet Sapi Bali di Kecamatan Nanaet Dubesi Kabupaten Belu tahun 2016 mencapai 375 ekor $(44,9 \%)$ sedangkan pada tahun 2017 mencapai 460 ekor $(55,1 \%)$. Angka pemotongan dan kehilangan ternak sapi di Kecamatan Nanaet Dubesi Kabupaten Belu pada tahun 2016 adalah $0,06 \%$ dan 0,9\%, sedangkan pada tahun 2017 adalah 2,24\% dan 1,1\%. Angka penjualan Sapi Bali di Kecamatan Nanaet Dubesi Kabupaten Belu pada tahun 2016 mencapai 6,68\%, sedangkan pada tahun 2017 mencapai 48,28\%. Faktor-faktor yang mempengaruhi mortalitas, calving rate, angka pemotongan dan kehilangan, penjualan dipengaruhi oleh faktor ketersediaan pakan, iklim, penyakit, tatalaksana pemeliharaan serta karakteristik peternak.

\section{Pustaka}

Asana F., L. O Ba'a, R.Aka.2016. Pertambahan Alamiah Dan Distribusi Angka Kelahiran Sapi Bali Di Kota Baubau. Alumni Fakultas Peternakan Universitas Halu Oleo. Dosen Fakultas Peternakan Universitas Halu Oleo

Baco S. 2001. Perbandingan Bobot Badan dan Beberapa Ukuran Dimensi Tubuh Sapi Bali Betina yang Dipelihara Secara Ekstensif pada Daerah Dataran Rendah dan Pegunungan Di Kabupaten Bone. Laporan Penelitian Proyek DPP Universitas Hasanuddin.

Baco S. 2010. Performansi Sapi Bali pada Kawasan Instalasi populasi dasar Breeding Center di Kabupaten Bone. Prosiding Seminar Nasional Peternakan. Hal. 236 -245.

Badan Pusat Statistik Kabupaten Belu Tahun 2016

Chamdi A. N., 2003. Kajian Profil Sosial Ekonomi Usaha Kambing Di Kecamatan Kradenan Kabupaten Grobogan. Prosiding Seminar Nasional Teknologi Peternakan dan Veteriner. Bogor 29-30 September 2003.

Dania I. B., H. Poerwoto., R. A. Suhardiani., dan T. Hidjaz. 2013. Bahan Ajar Manajemen Ternak Potong Dan Kerja. Fakultas Peternakan Universitas Mataram. Mataram. Dania, I.B., Hidjaz, T., Andriani, R., Asih, M.S. 1996. Kapasitas Suplai Kerbau Bibit dan Potong di Pulau Sumbawa. Laporan penelitian. Fakultas Peternakan Universitas Mataram. Mataram.

Hartono B. 2005. Curahan Tenaga Kerja Keluarga Usaha Ternak Sapi Perah Kasus Di Desa Pandesari Kecamatan Pujon Kabupaten Malang. Buletin Peternakan. Vol. 29(3) 2005.

Idris N., Alfiani H. \& Fatati. 2009. Minat Peternak Untuk Mengembangkan Ternak Sapi di Kawasan Perkebunan Sawit. Program Studi Ekonomi Peternakan. Universitas Jambi. Jurnal Penelitian Universitas Jambi Seri Humaniora. Vol. 11(2). ISSN 0852-8349

Makatita J. 2013. Hubungan Antara Karakteristik Peternak Dengan Skala Usaha Pada Usaha Peternakan Kambing Di Kecamatan Leihitu Kabupaten Maluku Tengah. Agrinimal, 3(2) p:78-83

Mulik M dan I. G.N Jelantik., 2009. Strategi Peningkatan Produktivitas Sapi Bali Pada Sistem Pemeliharaan ekstensif Di Daerah Lahan Kering: Pengalaman Nusa Tenggara Timur. Fapet Universitas Nusa Cendana.

Murwanto A. G. 2008. Karakteristik Peternak dan Tingkat Masukan Teknologi Peternakan Sapi potong di lembah Prafi Kabupaten Manokwari. Jurnal ilmu Peternakan. 3(1) p: 8-15

Pontianakpos. com.id. 2016. Perlindungan dan risiko kematian serta kehilangan sapi. edisi 24 Mei 2016. Diakses pada 22 Mei 2018.
Sariubang M, R. Qomariyah \& L. Kristanto. 2010. Peranan Ternak Kerbau Dalam Masyarakat Adat Toraja Di Sulawesi Selatan. Seminar Nasional Teknologi Peternakan dan Veteriner. Balai Pengkajian Teknologi Pertanian Sulawesi Selatan, Jl. Perintis Kemerdekaan Km. 17,5, Makassa Saputra E. D. 2008. Sapi Bali sebagai plasma nutfah dan peranannya bagi petani. [On Line]. [28 Agustus 2010].

Siregar W P. 2013. Faktor - Faktor Yang Mempengaruhi Usaha Ternak Sapi Potong Di Desa Mangkai Lama Kecamatan Lima Puluh Kabupaten Batubara Provinsi Sumatera Utara. Skripsi. Departemen Agribisnis Fakultas Ekonomi Dan Manajemen Institut Pertanian Bogor

Soekartawi 2002. Prinsip Dasar Ekonomi Pertanian Teori dan Aplikasi. Jakarta: PT. Raja Grafindo.

Sugiyono 2007. Metode Penelitian. Jakarta: CV. Alfa Beta

Thalib R.B., Entwistle, K., Siregar, A., Budiarti-Turner, S., dan Lindsay, D. 2003. Survey population and production dynamics of Bali Cattle and existing breeding programs in Indonesia. Dalam Strategies To Improve Bali Cattle In Eastern Indonesia. ACIAR Proceedings No.110. Editors: K. Entwistle dan D. Lindsay.

Trigestianto M., S Nur, \& Moch. Sugiarto. 2013. Analisis tingkat Kesejahtraan Peternak Sapi Potong di Kabupaten Purbalingga. Fakultas Peternakan Universitas Jenderal Soedirman. Jurnal Ilmiah 1(3) p: 1158-1164 September 2013

Utami L.S. Syahdar Baba \& S. N. Sirajuddin. 2016. Hubungan Karakteristik Peternak Dengan Skala Usaha Ternak Kerbau Di Desa Sumbang Kecamatan Curio Kabupaten Enrekang. Fakultas Peternakan Universitas Hasanuddin, Makassar . JITP 4 (3)

Waris N Badriyah, D Wahyuning A. 2015. Pengaruh Tingkat Pendidikan Dan Lama Beternak Terhadap Pengetahuan Manajemen Reproduksi Ternak Sapi Potong Di Desa Kedungpring Kecamatan Balongpanggang Kabupaten Gresik. Program Studi Peternakan. Universitas Islam Lamongan. Jurnal ternak Vol. 06 No. 01 Juni 2015. 